\title{
„Uczyńmy Hiszpanię wielką”. Partia Vox jako krystalizacja radykalnej prawicy na Półwyspie Iberyjskim
}

\begin{abstract}
Streszczenie: Artykuł przedstawia fenomen krystalizacji radykalnej prawicy na hiszpańskiej scenie politycznej w kontekście sukcesów politycznych partii Vox. Ukazuje uwarunkowania polityczne i społeczne, oddziałujące na pojawianie się tej formacji, a także jej główne postulaty oraz zaplecze ideologiczne. Odpowiada na pytanie, na jakich płaszczyznach dyskursywnych partia Vox inkorporowała do swej narracji wątki nacjonalistyczne i natywistyczne. Artykuł analizuje przesłanki poparcia dla tego ugrupowania i ukazuje profil społeczny jego wyborców. Analiza ta bazuje na integracji metod historycznej i systemowej oraz - diagnozując fenomen ugrupowania Vox - odwołuje się do pojmowania radykalnej prawicy w ujęciu Casa Mudde'a. Głównym wnioskiem płynącym z zawartych w niej obserwacji jest stwierdzenie, że po latach nieobecności na hiszpańskiej scenie politycznej radykalnej prawicy partia o takim charakterze zdołała na niej zaistnieć i zająć znaczące miejsce. Jej przekaz znalazł odzwierciedlenie u wyborców reprezentujących postawy antysystemowe, rozczarowanych tradycyjnym układem sił politycznych. Artykuł wskazuje na te wątki dyskursywne partii Vox, które odwołują się do postaw konserwatywnych, ożywiają resentymenty historyczne oraz krytycznie postrzegają rozwój społeczeństwa wielokulturowego, upatrując w nim zagrożenie dla tradycyjnie rozumianych wartości i kultury Hiszpanii.
\end{abstract}

Słowa kluczowe: Vox, Hiszpania, radykalna prawica, nacjonalizm, imigranci, tożsamość

$\mathbf{N}$ a przestrzeni ostatnich lat zaznacza się w Europie aktywizacja ugrupowań populistycznych i skrajnie prawicowych, które m.in. występują w obronie zagrożonych, jak twierdzą, wartości tradycyjnych, czy też podsycają obawy przed ,islamizacją” społeczeństw Starego Kontynentu, łącząc radykalizm salaficki i kreowane przezeń wyzwania z problemem napływu imigrantów i uchodźców. Kwestia stosunku do nich i wielokulturowego charakteru części społeczeństw europejskich jest szczególnie istotna w kontekście percepcji mieszkających na Starym Kontynencie wspólnot wyznawców islamu. Jest też obecna w przesłaniu politycznym reprezentantów różnych ugrupowań politycznych w Europie, w tym także tych o profilu antyimigranckim, instrumentalizujących zagrożenie ze strony terroryzmu dżihadystycznego. Przykładami takich organizacji są hiszpańska partia Vox, Alternatywa dla Niemiec, Szwedzcy Demokraci, francuski Front Narodowy. Ich dyskurs charakteryzuje natywizm oraz odzwierciedla społeczne obawy przed demonizowanym i stygmatyzowanym, ,innym” i m.in. na ich podstawie usiłuje zdyskontować poparcie (Gómez-Reino Cachafeiro, 2019, s. 1-2).

Hiszpania jest w tym sensie państwem szczególnym. Pomimo krystalizacji na jej terytorium bezpośrednich zagrożeń terrorystycznych, czego wyrazem były zamachy w 2004 r. w Madrycie i w 2017 r. w Katalonii oraz szereg operacji antyterrorystycznych, dzięki którym rozbito wiele komórek związanych z siecią Al-Kaidy i tzw. Państwem Islamskim (Kosmynka, 2020a, s. 143-156), hiszpańskie społeczeństwo nie było szczególnie podat- 
ne na dyskurs sił skrajnie prawicowych. Postawy niechętne wobec mieszkających w tym państwie ok. 2 mln muzułmanów znajdują, co prawda, nierzadko swój wyraz, ale trudno je uznać za przejawy głęboko zakorzenionej społecznie islamofobii. Na przestrzeni kilku dekad, które upłynęły od zakończenia dyktatury gen. Franco, w państwie tym zaszły istotne zmiany społeczne, nie pozostające bez wpływu również i na sferę polityki. Laicyzacja i liberalizacja obyczajowa, proces emancypacji kobiet i uzyskanie przez społeczności LGBT szerokiego pakietu praw wpłynęły z kolei na aktywizację nurtów konserwatywnych, kontestujących te procesy. Nie sposób nie wspomnieć o oddziaływaniu na instytucjonalizację tych ruchów także innych ważnych czynników: narastających tendencji separatystycznych w Katalonii czy postępującej budowy społeczeństwa wielokulturowego, postrzeganego jako zagrożenie dla integralności i tożsamości Hiszpanii.

$\mathrm{W}$ ostatnich latach dyskurs antyimigrancki jest jednak bardziej wyraźny we frazeologii przedstawicieli środowisk konserwatywnych, występujących w obronie rzekomo zagrożonych żywotnych interesów społeczeństwa hiszpańskiego. O tendencji tej świadczą wyniki wyborów parlamentarnych w 2019 r. i sukces prawicowej partii Vox, która zdobyła ok. 15 proc. głosów, choć oczywiście nie tylko w tych czynnikach należy poszukiwać przyczyn wzrostu poparcia dla tej formacji. Nastroje te wpisują się w szeroko reprezentowany w Europie kontekst sekurytyzacji migracji - proces włączania określonych tematów do kwestii bezpieczeństwa, czemu niejednokrotnie towarzyszy wspominana demonizacja „obcego” (Huysmans, 2000, s. 751; Ziętek, 2017, s. 31).

Celem artykułu jest przedstawienie głównych postulatów ideowych partii Vox i ukazanie tegoż ugrupowania jako reprezentanta radykalnej prawicy w Hiszpanii. Podstawowe pytania badawcze dotyczą czynników, którym zawdzięcza ono zaistnienie na scenie politycznej tego państwa. Warto jednocześnie dociec, na poparcie jakich grup społecznych może ona liczyć i o czyje głosy szczególnie zabiega. Głównym założeniem niniejszych rozważań jest stwierdzenie, że zachodzące w Hiszpanii na przestrzeni ostatnich lat transformacje społeczne i kulturowe, zaktywizowały kontestujące te przemiany środowiska tradycjonalistyczne, których reprezentacją polityczną stała się w ostatnich latach partia Vox. Zarazem dla środowisk tych oferta istniejących od dawna na hiszpańskiej arenie politycznej nurtów prawicowych i konserwatywnych okazała się niewystarczająca.

\section{Aspekt metodologiczny}

Stanowiący podstawę niniejszej analizy problem badawczy implikuje potrzebę wykorzystania interdyscyplinarnego wachlarza metod. Pomocna okazała się integracja metody historycznej - szczególnie w kontekście uchwycenia relacji przyczynowo-skutkowych krystalizacji określonych mechanizmów - oraz systemowej, pozwalającej na ujęcie omawianych zagadnień jako powiązanego zespołu elementów, w ramach którego uwaga skupia się zarówno na ich częściach składowych, jak i wzajemnych korelacjach. Metoda historyczna rozumiana jest $\mathrm{w}$ tej analizie w ujęciu zaproponowanym przez Andrzeja Chodubskiego. Określają ją m.in. ,[...] takie elementy jak: badanie genezy zjawisk politycznych, traktowanie łącznie ich aspektów strukturalnych, funkcjonalnych i genetycznych [...]" (Chodubski, 2004, s. 127). Diagnoza omawianej problematyki okazała się możliwa w dużym stopniu także dzięki pobytom studyjnym w Andaluzji, 
w Katalonii oraz w Madrycie, jak również prowadzonym tam obserwacjom i wywiadom eksperckim. Wyjazdy do Katalonii, Andaluzji i Madrytu zrealizowane były w latach 2018-2019. W ich trakcie miały miejsce spotkania z przedstawicielami Vox-u i Partii Ludowej w lokalnych biurach tych formacji oraz w ośrodkach akademickich: na Uniwersytetach w Granadzie oraz Madrycie.

Jakkolwiek współczesnemu rozwojowi ugrupowań radykalnej prawicy w Europie poświęconych jest szereg publikacji polsko- i obcojęzycznych, to zagadnienie krystalizacji tego nurtu w Hiszpanii bywa poddawane analizie przede wszystkim przez badaczy hiszpańskich, takich jak m.in.: Carles Ferreira, Margarita M. Gómez-Reino Cachafeiro, Xavier Casalas, Victor Climent Sanjuan, Mirian Montaner Goetzenberger. Autorzy ci koncentrują się na ukazaniu uwarunkowań politycznych i katalizatorów społecznych pojawienia się skrajnej prawicy w Hiszpanii oraz jej miejsca w tym państwie.

Vox jest określany jako ugrupowanie radykalnie prawicowe, jedyne - jak dotychczas - o takim odcieniu na hiszpańskiej scenie politycznej, któremu udało się dyskontować znaczące sukcesy. W niniejszej analizie radykalna prawica jest rozumiana przez pryzmat ujęcia zaproponowanego przez Casa Mudde'a jako nurt, który kwestionuje niektóre aspekty demokracji liberalnej, takie jak np. pluralizm polityczny, niezależność instytucji publicznych, czy ochrona praw mniejszości, ale nie odrzuca demokracji jako takiej, co oznaczałoby wezwanie do zastąpienia jej innym rozwiązaniem systemowym (Mudde, 2018; Amengay, Stockemer, 2018, s. 4). Cechą charakteryzującą tę formację są zazwyczaj nacjonalizm i mitologizowanie przeszłości historycznej. Ważnym elementem konstruowania narracji bywa często dyskurs populistyczny, choć trzeba zaznaczyć, że ten z kolei bywa strategią znamienną dla środowisk i liderów politycznych różnych orientacji (dość wspomnieć latynoamerykańską lewicę populistyczną tak wyraziście egzemplifikowaną w minionej dekadzie przez prezydenta Wenezueli Hugo Chaveza). Słusznie podkreślając, że współczesna aktywność partii o tym profilu nie jest zjawiskiem nowym, Dominika Kasprowicz wskazuje, że ,[...] populistyczna skrajna prawica jest przykładem sukcesu zarówno w sensie artykulacji nowego zestawu postulatów, instytucjonalizacji struktur organizacyjnych, rosnącego poparcia wyborczego dla tych partii, jak i ich relewancji w systemie politycznym - udziale w procesie decyzyjnym" (Kasprowicz, 2017, s. 9).

Populizm z kolei jest rozumiany w tej analizie w kategorii określonej strategii walki o władzę bądź jej sprawowania. Jest to styl przywództwa politycznego, który charakteryzuje bezpośrednia, paternalistyczna i charyzmatyczna więź łącząca lidera i jego zwolenników. Występuje on w imieniu ludu i przeciwstawia jego interesy skorumpowanym elitom w celu zdyskontowania poparcia mas, będących jego klientelą polityczną i spajanych wiarą w szczególne zdolności i predyspozycje lidera (Freidenberg, 2007, s. 25). Populizm obiecuje zmiany i wypowiada się przeciwko rządzącemu establishmentowi oraz nierzadko domaga się przekształceń systemowych. Wypowiedzi polityków stosujących takie narzędzie dyskursywne, cechuje swoista „plastyczność ideologiczna”, polegająca na dostosowywaniu przekazu i wizerunku do oczekiwań mas oraz czerpaniu korzyści politycznych z kryzysu.

Jak zauważa Vargas Paredes, populistyczny przywódca tak naprawdę nie stara się rozwiązać problemów społecznych, a jedynie ,administruje nimi” w celu pozyskania głosów, aby następnie wcielać w życie eksperymenty ustrojowe zagrażające w istocie 
demokracji (Sául Vargas Paredes, 2009, s. 23). Przekaz polityczny, jaki populizm proponuje, oparty jest na konstrukcji manichejskiej, polegającej na ukazaniu walki politycznej w kategoriach konfrontacji dobra ze złem. Lider jest kreowany na wybawiciela, uosabia nadzieję na zmiany, natomiast jego oponenci zazwyczaj bywają przedstawiani jako inkarnacja zła i problemów, z którymi boryka się państwo (de la Torre, 2007, s. 59). Frazeologia populistyczna jest przesycona dychotomią sytuującą na przeciwległych biegunach lud i elity (np. „oligarchów”), dlatego też tak ważną rolę w komunikacie politycznym adresowanym do wyborców pełnią kategorie wrogów i zagrożeń, przyczyniające się do polaryzacji społecznej oraz mobilizacji adresatów takiego przekazu. Charyzma jest mocno wpisana $\mathrm{w}$ ten rodzaj przywództwa, ponieważ wyraża on, $\mathrm{z}$ jednej strony, potrzebę istnienia lidera, który ogniskuje uwagę i poparcie otoczenia, zaś z drugiej stanowi uosobienie mniej lub bardziej wyrazistego projektu politycznego. Populizm często okazuje się rodzajem strategii mobilizacji społecznej dokonywanej właśnie przez charyzmatycznych przywódców.

\section{Krystalizacja radykalnej prawicy w Hiszpanii}

Po upadku frankizmu przez długi czas nurty reprezentujące w Hiszpanii skrajną prawicę cechowało rozdrobnienie i bardzo niewielki poziom poparcia społecznego. Ich aktywizacja zaznaczała się przede wszystkim w trzech ośrodkach: Madrycie, Barcelonie, Walencji. Jeszcze w okresie trwania dyktatury pojawiły się ruchy neofaszystowskie, takie jak założony w 1966 r. Hiszpański Krąg Przyjaciół Europy (Círculo Español de Amigos de Europa - CEDADE), czy - powstałe już w nowej rzeczywistości politycznej - ugrupowanie Transformacja wraz z Frontem Narodowym Młodzieży (Transición con la Frente Nacional de Juventud - FNJ). Inicjatywy te miały jednak znaczenie marginalne i nie mogły liczyć na znaczący odzew społeczny (Marcet, 2012, s. 18-20). Narodowo-konserwatywny reżim dyktatorski skutecznie zagospodarowywał prawą część hiszpańskiej sceny politycznej i kiedy nastąpił jego kres, uwidoczniły się alternatywne tendencje, będące reakcją na długotrwały brak wolności, nie tylko w sferze politycznej, ale także pod postacią ruchów kontrkulturowych, takich jak np. słynna movida w Madrycie.

Śmierć generała Franco (1975 r.) oraz przebudowa systemu politycznego, która nastąpiła w konsekwencji reorientacji politycznej w Hiszpanii, zaktywizowały siły prodemokratyczne i lewicowe, które nie mogły rozwijać się w warunkach dyktatury. To ich dominacja nadała ton przeobrażeniom ustrojowym i społecznym w tym państwie. Pluralizm polityczny umożliwił im rozwój i przysporzył poparcia społecznego ze strony środowisk spragnionych wolności. Trzeba zaznaczyć, że największe ugrupowanie konserwatywne - Partia Ludowa (Partido Popular) - również stało się ważnym aktorem na hiszpańskiej scenie politycznej, wpisującym się w kontinuum systemu demokracji liberalnej. Partia ta, wokół której skupione były różne środowiska, w tym także te prezentujące frankistowskie resentymenty, przez długi czas skutecznie monopolizowała prawą stronę tej sceny. Inicjatywy niezależne i alternatywne, jak te wymienione poniżej, nie były na tyle silne, aby stać się częścią mainstreamu hiszpańskiej polityki i uzyskać szerszy rezonans społeczny. Hiszpańska skrajna prawica nie była w stanie przystosować 
się do nowej rzeczywistości politycznej, jej przekaz był postrzegany jako anachroniczny i za bardzo kojarzył się z ancien regimem.

Dążenie do zagospodarowania niewielkich, jak się okazało, nostalgii za dyktaturą znalazło wyraz w profilu ugrupowania Nowa Siła (Fuerza Nueva), która w 1979 r. zdobyła jedynie ok. 2 proc. głosów (Casalas, 2017, s. 4). Wynik ten symbolicznie oznaczał zarazem niski poziom poparcia dla środowisk skrajnej prawicy w hiszpańskim społeczeństwie okresu tranzycji demokratycznej, co dobitnie potwierdziła nieudana próba przewrotu wojskowego w lutym 1981 r. (Cercas, 2009). Inne konserwatywne projekty, jak Sojusz Ludowy (Alianza Popular - AP) Manuela Fragi Iribarne czy Związek Demokratycznego Centrum (Unión de Centro Democrático - UCD) Adolfo Suareza, określiły prawą stronę sceny politycznej okresu przemian. W kolejnych dekadach pojawiały się, co prawda, inicjatywy stworzenia reprezentacji politycznej nurtów nacjonalistycznych, takich jak m.in. powołana w 1995 r. Narodowa Demokracja (Democracia Nacional), jednak przedsięwzięcia te nie były udane i przede wszystkim nie mogły liczyć na szersze społeczne poparcie. Środowiska te nie posiadały wyrazistego przywództwa politycznego, co niewątpliwie utrudniało im pozyskanie sympatyków. Dopiero na początku XXI w. można mówić o powolnym zagospodarowywaniu przez hiszpańską ultraprawicę pustego dotąd miejsca na arenie politycznej, czego wyrazem stała się Platforma dla Katalonii (Plataforma per Catalunya - PxC), aktywna w tym regionie od 2003 r. i głosząca potrzebę „uregulowania kwestii imigracyjnej” (Casalas, 2017, s. 5). Ugrupowanie to nie identyfikowało się z żadną stroną sceny politycznej i określało się jako obywatelskie, akcentując potrzebę rozwiązania takich wyzwań jak terroryzm, degradacja środowiska naturalnego, problemy społeczne i gospodarcze itp. Jednocześnie we frazeologii ugrupowania, które wraz z końcem pierwszej dekady XXI w. odnotowało pewne sukcesy na scenie politycznej, silnie pobrzmiewały akcenty antyislamskie. Próbowało ono zaistnieć także w innych częściach kraju, a szczególnie w dużych miastach; dość wspomnieć o jego „filiach” w Kastylii i León, Walencji, okręgu stołecznym, jednak poczynania te nie okazały się efektywne. Platforma dla Katalonii występowała również przeciwko tendencjom separatystycznym w tym regionie, które wyraźnie nasiliły się u schyłku XX w. i w pierwszych dekadach XXI w. Wskutek m.in. problemów wewnętrznych, w kolejnych latach popularność PxC wyraźnie zmalała.

Inicjatywą o podobnej orientacji ideowej, która również nie zaistniała na trwałe w pejzażu politycznym tego państwa, była Hiszpania 2000 (Esp2000) kierowana przez przedsiębiorcę i adwokata José Luisa Roberto. Określała się jako „partia o charakterze socjalnym i patriotycznym, która broni interesów obywateli przed zakusami rządów regionalnych i zagrożeniami zewnętrznymi” (Casalas, 2017, s. 7). Odniosła ona pewne niewielkie sukcesy w wyborach lokalnych w okręgu Madrytu, jednak także i w tym przypadku trudno uznać te działania za udane.

\section{Fundamenty ideowe partii Vox}

Jak zaznaczono, Vox bywa określany jako ugrupowanie radykalnie prawicowe, łączące neoliberalizm ekonomiczny z politycznym nacjonalizmem (Rubio-Pueyo, 2019, s. 3). Powstało ono w grudniu 2013 r. i jego początkowym celem było zdobycie miejsc 
w Parlamencie Europejskim; deklarowano tu zamysł reprezentowania interesów narodowych oraz przeciwstawienie się ingerującym rzekomo zbyt daleko w wewnętrzne kompetencje państw członkowskich rozwiązaniom UE. Organizację tę cechował krytyczny stosunek do władz Partii Ludowej (z jej szeregów wywodziła się zresztą znaczna część członków Vox-u), w tym także do jej przywódcy, Mariano Rajoya, który w ich opinii uchodził za zbyt umiarkowanego. Liderem ugrupowania został były polityk Partido Popular Santiago Abascal. Deklaracja programowa obejmowała bardzo ogólne postulaty jak: ochrona wartości tradycyjnych, poprawa efektywności funkcjonowania instytucji publicznych, zapewnienie zrównoważonego rozwoju gospodarczego, dbałość o wysokie kompetencje etyczne osób pełniących funkcje w administracji publicznej itp. (Ferreira, 2019, s. 76). Początkowo nie były tam eksponowane wątki dotyczące imigrantów, jednak z czasem kwestia ta zajęła istotne miejsce w programie tej formacji.

Przez pierwsze lata istnienia partia ta nie odnotowała istotnych sukcesów w wyborach, ciesząc się bardzo nikłym poparciem społecznym, i można było przewidywać, że podzieli los innych radykalnie prawicowych ugrupowań, które bez widocznych rezultatów próbowały zaistnieć na hiszpańskiej scenie politycznej. Dopiero wybory w Andaluzji w grudniu 2018 r. przyniosły uzyskanie przez Vox ponad 10 proc. poparcia, co przełożyło się na 12 miejsc w parlamencie tego regionu (Ortiz Barquero, 2019, s. 3). W maju 2019 r. w wyborach do Parlamentu Europejskiego ugrupowanie zdobyło 6,2 proc. głosów. W tym samym roku, w kwietniu, uzyskało ponad 10 proc. głosów w wyborach powszechnych i 24 miejsca w Parlamencie. Wskutek kryzysu politycznego w Hiszpanii w listopadzie 2019 r. odbyły się przedterminowe wybory, w wyniku których Vox umocnił swoją pozycję: było to ponad 15 proc. poparcie (przeszło 3,6 mln głosów), co zaowocowało 52 mandatami w Parlamencie (González, 2019). Wyniki te obrazują ewidentny sukces ugrupowania, które zagospodarowało część elektoratu prawicy i postaw antysystemowych.

Progresowi temu towarzyszyła zauważalna radykalizacja ugrupowania, w dużym stopniu wynikająca z potrzeby odróżnienia się od bardziej umiarkowanej Partii Ludowej, zaznaczenia swej wyrazistości i zdobycia głosów osób o poglądach prawicowych, zniechęconych do hiszpańskiej klasy politycznej oraz pragnących zmiany. Na wzrost poparcia dla Vox-u rzutował również kryzys polityczny w Hiszpanii oraz odczuwane przez wielu obywateli zmęczenie patem między dużymi partiami, niezdolnymi do samodzielnego rządzenia. Profil partii odzwierciedlały spotkania z liderami populistycznych ugrupowań prawicowych w Europie: Marie Le Pen (francuski Front Narodowy/Zjednoczenie Narodowe) Frauke Petry (Alternatywa dla Niemiec), Geertem Wildersem (holenderska Partia Wolności) oraz Stevem Bannonem, bliskim współpracownikiem prezydenta USA Donalda Trumpa. Współpraca ta zaowocowała jednoznacznym zakotwiczeniem partii Vox wśród ugrupowań radykalnych i konserwatywnych, występujących zdecydowanie przeciwko nielegalnej imigracji, czego wyrazem był akces w Parlamencie Europejskim do grupy Tożsamość i Demokracja (ID), wzywającej do większej suwerenności państw członkowskich w ramach UE.

W odniesieniu do działań realizowanych na arenie krajowej, Vox deklarował gotowość do współpracy z Partią Ludową oraz ugrupowaniem Obywatele (Ciudadanos) w celu osłabienia rządzących socjalistów - PSOE (Partido Socialista Obrero Español) i premiera Pedro Sancheza. Należy jednak podkreślić, że ważnym elementem narracji 
tej partii, szczególnie akcentowanym w pierwszym okresie po jej powstaniu, była niechęć do tradycyjnych ugrupowań politycznych i typowa dla ruchów populistycznych krytyka „elit” oraz istniejącego układu sił. Jednocześnie w dyskursie Vox-u wyraźnie zaznaczyły się kwestie podejmowane również przez bliskie ideowo temu ugrupowaniu siły w innych państwach UE: m.in. postulaty zwalczania ruchów i ,ideologii” LGBT, obrony rodziny i tradycyjnych wartości narodowych, ograniczenia imigracji, obniżenia podatków, poprawy stanu bezpieczeństwa. Partia reprezentuje stanowisko znamienne dla nurtów konserwatywnych konfrontujących się z opcjami pluralistycznymi i lewicowymi, w tym wspomnianymi środowiskami nieheteronormatywnymi, ruchami feministycznymi itp. Środowiska te zarzucają jej, że podnosząc hasło obrony tradycyjnych wartości, frazeologia Vox-u odzwierciedla zakotwiczenie w patriarchalnych stosunkach społecznych, o czym świadczy np. marginalizowanie problemu przemocy wobec kobiet, przeciwstawianie temu wyzwaniu kwestii „dyskryminacji mężczyzn” itp. (Chislett, 2018, s. 4). Partia wzywa zarazem do zmiany liberalnego prawa aborcyjnego w kierunku wprowadzenia regulacji znacznie je zaostrzających. Postuluje utworzenie centrów „ochrony życia” i wsparcia dla rodzin, a także dla kobiet znajdujących się w trudnej sytuacji ekonomicznej.

Vox proponuje aksjologiczną reorientację hiszpańskiej polityki. Wątki światopoglądowe zaznaczają się także w wielu innych sferach. W listopadzie 2020 r. Vox i Partia Ludowa protestowały przeciwko postulowanej przez rząd lewicowy reformie oświaty, m.in. obniżającej wiek rozpoczęcia edukacji seksualnej, wprowadzającej zajęcia z ekologii i feminizmu oraz ingerującej w system funkcjonowania placówek prywatnych (tzw. escuelas concertadas) (Bocanegra, 2020). Partia niejednokrotnie wyrażała sprzeciw wobec programu edukacji seksualnej w szkołach, sugerując jakoby przyczyniała się ona do promowania wczesnego współżycia, a także nieheteronormatywnych wzorców.

W programie formacji wyraźnie zaznaczają się oczywiście także kwestie krajowe, związane z kształtem ustrojowym państwa i towarzyszącym temu napięciom. Oznaczają one w tym sensie głównie przeciwstawianie się separatyzmom katalońskiemu i baskijskiemu, odwoływanie się do symboli narodowych i promowanie wizji Hiszpanii jako państwa zbudowanego na fundamencie kultury kastylijskiej (Ferreira, 2019, s. 78), o czym mowa dalej. Partię cechuje jednoznacznie nacjonalistyczny charakter, pozostający w opozycji do nacjonalizmów regionalnych, postrzeganych jako tendencje odśrodkowe, zagrażające hiszpańskiej racji stanu. Stanowisko to ilustrują postulaty delegalizacji partii separatystycznych.

Wielokrotnie z wypowiedzi polityków Vox-u wynika potrzeba ochrony dziedzictwa narodowego i budowania wspólnoty, której, wedle takiego ujęcia, zagraża rozwój społeczeństwa wielokulturowego, anihilującego „prawdziwie hiszpańską” tożsamość. W tym zakresie partia akcentuje konieczność zintensyfikowania działań na rzecz integralności Hiszpanii, rozumianej również $\mathrm{w}$ sensie symbolicznym poprzez przywiązanie do monarchii oraz supremacji języka hiszpańskiego na tle innych języków urzędowych tego państwa. Postrzegając Kościół katolicki jako jeden z filarów tożsamości, Vox deklaruje zasadność działań przeciwstawiających się laicyzacji, która od lat bardzo silnie się zaznacza w hiszpańskim społeczeństwie (https://www.voxespana.es/, 2021). Ugrupowanie podkreśla $\mathrm{w}$ tym kontekście potrzebę zachowania i ochrony dziedzictwa narodo- 
wego - za jeden $z$ istotnych jego elementów uważa np. - tak krytykowaną m.in. przez obrońców praw zwierząt - corridę. Nie sposób zarazem nie dostrzec w słowach jednego z czołowych polityków tego ugrupowania, Ortegi Smitha - ,razem uczynimy Hiszpanię znowu wielką!" (https://www.voxespana.es/noticias/ortega-smith-cada-vez-somosmas-espanoles-dispuestos-cambiar-rumbo-espana-20191031, 2021) - odwzorowania głównego hasła wyborczego kampanii Donalda Trumpa: „Uczyńmy Amerykę znowu wielką!" (Make America Great Again).

Wspomniana wcześniej praktyka mitologizacji przeszłości, znamienna dla dyskursu radykalnej prawicy, w odniesieniu do partii Vox znajduje odzwierciedlenie w stosunku do Al-Ándalus - wielowiekowej obecności cywilizacji muzułmańskiej na Półwyspie Iberyjskim. Nie sposób zrozumieć społeczeństwa i kultury Hiszpanii bez odniesień do tego okresu. Jak wiadomo, władanie to pozostawiło wielopłaszczyznowy wpływ, prowadząc do krystalizacji różnorodnych form synkretycznych, zaś jego pozostałości są obecne po dziś dzień, nie tylko zresztą pod postacią artefaktów historycznych (Lipczak, 2020). Obecność islamu w tej części Europy oraz - zarówno harmonijne, jak i antagonistyczne - złożone interakcje mieszkających obok siebie chrześcijan, muzułmanów i żydów, w kolejnych stuleciach nabrały uproszczonego i odbiegającego od zawiłości prawd historycznych obrazu minionych czasów i procesów. Demitologizacja przeszłości wydaje się tymczasem szczególnie potrzebna z perspektywy łagodzenia współczesnych napięć politycznych, które pragną zdyskontować siły instrumentalizujące owe mity (z jednej strony radykalna prawica, $\mathrm{z}$ drugiej zaś nurty dżihadystyczne, wzywające do „odzyskania Al-Ándalus z rąk niewiernych”). Płynąca w tym względzie w stosunku do partii Vox krytyka ze strony środowisk lewicowych i liberalnych wskazuje, że formacji tej jest bliska postfrankistowska narracja historyczna, selektywnie odnosząca się do wydarzeń i faktów historycznych, dostrzegająca jedynie dodatnie znaczenie procesu rekonkwisty w procesie narodowotwórczym. Tak np. politycy Vox-u chętnie przywołują postać patrona Hiszpanii św. Jakuba, stylizowanego w minionych epokach na symbol rekonkwisty - ,pogromcę Maurów” (Santiago Matamoros). Innym przykładem takiego podejścia do złożoności dziejów Hiszpanii, a szczególnie jej południa, była inicjatywa radnych tego ugrupowania, która zaowocowała usunięciem w miasteczku Cadrete w Aragonii pomnika jednego z muzułmańskich władców, Abd ar-Rahmana III, którego rządy przyczyniły się do rozwoju regionu (Sasot, 2019, s. 5).

Filarem ideologicznym frankizmu był narodowy katolicyzm oraz frazeologia ukazująca homogeniczność społeczną i kulturową Hiszpanii. Przekaz taki okazał się wizją w istocie daleko różną od rzeczywistego charakteru hiszpańskiego społeczeństwa, będącego de facto mozaiką różnorodności i odmienności, w której tożsamości lokalne mają częstokroć o wiele większe znaczenie identyfikacyjne aniżeli przywiązanie do swoistego monizmu państwowo-narodowego. Vox jest ugrupowaniem o charakterze natywistycznym. Inkorporował do swego dyskursu te resentymenty w kontekście wyostrzania percepcji imigrantów jako „obcych”. Stanowisko to wyraża odczucia tej części społeczeństwa, która obawia się skutków postępującego procesu budowy wielokulturowości Hiszpanii, łącząc ów proces z kwestiami ekonomicznymi oraz zagrożeniami dla bezpieczeństwa. Pisząc o lansowanej przez tę formację wizji państwa scentralizowanego, monokulturowego, Carles Ferreira wskazuje na ksenofobiczny charakter wielu wypowiedzi polityków Vox-u, szczególnie nieprzychylnych wobec mieszkających w Hiszpanii mu- 
zułmanów oraz „wrogów wewnętrznych” (separatystów). Wystąpienia reprezentantów Vox-u piętnują tendencje odśrodkowe jako zagrażające interesowi narodowemu oraz tożsamości (Ferreira, 2019, s. 81; Programa electoral para..., 2020). Stanowisko takie implikuje krytykę idei silnej autonomii regionalnej, będącej ważnym efektem transformacji systemowej Hiszpanii po zakończeniu dyktatury. Tak np. w kampanii wyborczej w 2019 r. Vox postulował zawieszenie autonomii Katalonii w odpowiedzi na niekonstytucyjne próby uzyskania pełnego samostanowienia tego regionu.

Jeżeli założymy, że pod wieloma analizowanymi tu względami można w pewnym sensie uznać Vox za partię postfrankistowską, nie dziwi jej swoisty rewizjonizm historyczny. Dotyczy on szczególnie pamięci historycznej i okresu wojny domowej oraz reżimu, który ukonstytuował się po jej zakończeniu. Kierownictwo partii oponowało przeciwko celebrowaniu pamięci ofiar dyktatury, argumentując, że taka optyka jest jednostronna i oddaje słuszność tylko jednej stronie konfliktu, podczas gdy należałoby - wedle takiego stanowiska - oddać hołd wszystkim, którzy stracili życie. Ideologia Vox-u jest oczywiście jednoznacznie antylewicowa i postrzega ona PSOE jako głównego antagonistę na scenie politycznej. Orientacja ta wyznacza również jednak charakter stosunku do przeszłości i wpisuje się w rewizjonizm historyczny - to socjaliści i komuniści są uznawani za winnych destabilizacji politycznej Hiszpanii i wybuchu wojny domowej w drugiej połowie lat $30 \mathrm{XX}$ w. Należy jednak podkreślić, że takie stanowisko nie implikuje postulatu zastąpienia demokracji reżimem autorytarnym $i$ hasła restytucji jakiejś formy neofrankizmu (Ferreira, 2019, s. 89). Vox wpisuje się w nurt radykalnej prawicy w sensie krytyki niektórych elementów liberalnego ładu konstytucyjnego (stopnia autonomii regionów), praw mniejszości etnicznych i seksualnych itp., postrzeganych jako przejaw za daleko idącego permisywizmu ze strony państwa, tolerancji oraz zmian prawnych i społeczno-obyczajowych, wprowadzanych przez rządy lewicowe. Partia zagospodarowuje poglądy osób sprzeciwiających się przemianom kulturowym, mającym miejsce w Hiszpanii w ostatnich dekadach, a zarazem postrzegających tradycyjną prawicę (PP) jako nazbyt umiarkowaną i nieudolną.

W wielu wypowiedziach polityków tej partii wyraźnie zaznaczają się, jak wspomniano, wątki niechętne imigrantom oraz wielokulturowości. Jest to wątek tak często obecny w narracji nurtów określanych jako populistyczne i radykalnie prawicowe (Climent Sanjuan, Montaner Goetzenberger, 2020, s. 917). Przybysze z innych państw, w tym szczególnie tych pozaeuropejskich, wielokrotnie są obciążani odpowiedzialnością za działania przestępcze i terrorystyczne. W tym też kontekście Vox proponuje zaostrzenie prawa i realizację przedsięwzięć na rzecz poprawy poziomu bezpieczeństwa. Poglądy te wyrażają m.in. słowa lidera partii Santiago Abascala: „Hiszpania potrzebuje aby nasze babcie mogły spokojnie chodzić ulicami bez strachu, że przestępca - Hiszpan czy cudzoziemiec, choć w większości przypadków są to cudzoziemcy - wyrwie im torebkę" (thum. własne, Gran acto de VOX..., 2020). Konsekwencją takiego stanowiska jest postulat zaostrzenia instrumentów prawnych, służących powstrzymaniu nielegalnego napływu imigrantów na Półwysep Iberyjski. Politycy tego ugrupowania wielokrotnie krytykują władze państwa z powodu niedostatecznych, ich zdaniem, starań w kierunku poprawy ogólnego poziomu bezpieczeństwa i ograniczenia imigracji. Wzywają natomiast do relokacji imigrantów, którzy przybyli bez stosownych pozwoleń na terytorium Półwyspu Iberyjskiego, oznaczającą w praktyce ich deportację. Czynnikiem ułatwiającym apli- 
kację takich rozwiązań miałaby okazać się pomoc gospodarcza skierowana dla państw, z których wywodzą się przybysze, w tym zwłaszcza dla regionu Sahelu (Kosmynka, 2020b, s. 103-116), będąca elementem Narodowego Planu Współpracy Międzynarodowej (Plan Nacional de Cooperación Internacional) (Gómez-Reino Cachafeiro, 2029, s. 9).

Łączenie problemu przestępczości z napływem imigrantów jest oczywiście chwytliwym hasłem, obrazującym znamienną dla narracji nurtów populistycznych dychotomiczną diagnozę problemu. $Z$ jednej strony, należy wskazać, że w Hiszpanii istotnie wielu cudzoziemców, m.in. wywodzących się Ameryki Łacińskiej oraz regionu Maghrebu, głównie Maroka, wchodzi w konflikt z prawem, co jest szczególnie widoczne W odniesieniu do procederu obrotu substancjami psychoaktywnymi . Z drugiej strony, warto podkreślić, że - wbrew obiegowym opiniom - wzrost liczby imigrantów oraz ich kolejnych pokoleń urodzonych już na terenie państwa przyjmującego - nie generuje nasilenia działalności przestępczej. Wskazują na to rezultaty szeregu badań, przeprowadzonych m.in. przez Centrum Badań Socjologicznych (CIS - Centro de Investigaciones Sociológicas) czy Narodowy Instytut Statystyczny (INE - Instituto Nacional de Estadística). Tak np. w 2017 r. imigranci odpowiedzialni byli za ok. 25 tys. popełnionych przestępstw, podczas gdy aż 303 tys. dopuścili się Hiszpanie. Przypadki naruszenia prawa spowodowane przez cudzoziemców dotyczyły 23 proc. ogółu mających miejsce w tym czasie aktów kryminalnych (García Espada, 2028, s. 7; ¿Cometen los extranjeros..., 2019). Pewien odsetek przybyszów rzeczywiście podejmuje działania łamiące prawo, zarazem jednak przywołane analizy podważają twierdzenie, jakoby wraz z napływem imigrantów i krystalizacją społeczeństwa wielokulturowego alarmująco rosły wskaźniki zachowań kryminogennych (Kosmynka, 2020c, s. 118). Warto zarazem dodać, że badania przytoczone przez Victora Climent Sanjuan i Mirian Montaner Goetzenberger wskazują, że, wbrew obiegowym opiniom, społeczeństwo Hiszpanii nie wyróżnia się na tle innych państw europejskich jako o wiele bardziej otwarte i tolerancyjne (Climent Sanjuan, Montaner Goetzenberger, 2020, s. 918). Jakkolwiek stosunek do imigrantów nie zawsze jest wprost proporcjonalny do poziomu poparcia dla partii natywistycznych, to jednak pojawienie się w ich narracji, nawiązujących do tej kwestii, rezonujących społecznie, elementów dyskursywnych może przyczynić się do instytucjonalizacji tych nurtów.

W odniesieniu do imigrantów oraz kolejnych ich pokoleń, przekaz partii Vox, jak zaznaczono, często uwzględnia wątek społeczności muzułmańskich. Retoryka polityków tego ugrupowania wielokrotnie odzwierciedla niechętny stosunek do mieszkających na terenie Hiszpanii wyznawców islamu. Postrzegani są oni jako kulturowo obcy, niewykazujący należytych starań na rzecz integracji ze społeczeństwem przyjmującym. Ponadto, niebagatelną rolę $\mathrm{w}$ takim wizerunku odgrywa powracające $\mathrm{w}$ wypowiedziach przedstawicieli Vox-u wskazywanie na związki łączące muzułmanów z zagrożeniami dla bezpieczeństwa - przestępczością i terroryzmem. Przekaz ten nabrał szczególnego znaczenia na przestrzeni ostatnich kilkunastu lat w kontekście zagrożeń terrorystycznych, ale także odrębności kulturowej społeczności napływowych czy kwestii ekonomicznych. Vox podkreśla m.in. potrzebę większej kontroli nad muzułmańskimi centrami religijnymi i ośrodkami kulturalnymi w celu monitorowania tych instytucji pod kątem rozpowszechniania w nich treści o charakterze salafickim. 


\section{Profil społeczny sympatyków partii Vox}

W świetle powyższych uwag jest oczywiste, że poparcie dla Vox-u reprezentują osoby o poglądach głęboko konserwatywnych, często deklarujące m.in. przywiązanie do praktyk religijnych. Wedle badań CIS wcześniej zazwyczaj głosowały one na Partię Ludową lub w ogóle nie uczestniczyły w wyborach (Cs crece en la encuesta..., 2021). Co ciekawe, w odróżnieniu od elektoratu partii o podobnej orientacji w innych państwach, wśród którego wyróżniają się często osoby starsze i posiadające niższe wykształcenie, wielu sympatyków Vox-u jest młodych i ma 25-38 lat, zaznacza się wśród nich spora grupa mężczyzn aktywnych zawodowo, powyżej 35 roku życia. Są to głównie drobni przedsiębiorcy, prowadzący własną działalność gospodarczą oraz rolnicy. Politycy należący do tego ugrupowania akcentują potrzebę ochrony miejsc pracy i wsparcia dla rodzimego biznesu, ostro krytykując m.in. rządową strategię walki z pandemią koronawirusa, prowadzącą - ich zdaniem - do bankructwa wielu firm i zapaści gospodarczej państwa.

Wiosną 2019 r. osoby aktywne zawodowo stanowily prawie 60 proc. elektoratu partii, podczas gdy emeryci - około 20 proc., a studenci - jedynie 6,5 proc. (Turrnbull-Dugarte, Rama, Santana, 2020, s. 4-7). Z badań wynika, że zdecydowaną większością, bo aż 70 proc. głosujących na tę partię, okazują się być mężczyźni - zazwyczaj bardziej podatni na hasła autorytarne - zaś blisko 50 proc. elektoratu zamieszkuje miejscowości poniżej 50 tys. mieszkańców (Turrnbull-Dugarte, Rama, Santana, 2020, s. 7). Jeśli chodzi o regiony, gdzie odnotowano największe poparcie dla Vox-u, wyróżniają się tutaj szczególnie Andaluzja, Murcja, Walencja, Kastylia La Mancha oraz dwa miasta-eksklawy: Ceuta i Melilla, położone na styku UE i Afryki, Europy i świata islamu. W tych dwóch ośrodkach szczególnie silnie zaznaczają się obawy przed ich „islamizacją”.

Sympatycy ugrupowania są zazwyczaj negatywnie nastawieni do sił politycznych sprawujących dotychczas władzę w Hiszpanii - oczywiście przede wszystkim do PSOE, ale także są rozczarowani Partią Ludową. Bardzo krytycznie oceniają sytuację polityczną w tym państwie. Należy dodać, że do sukcesu Vox-u przyczynił się też element pewnego novum, będący efektem niedawnego powstania formacji, kierującej swój program do tej części społeczeństwa, dla której ważne są eksponowane przez partię wątki - postulaty ochrony dziedzictwa kulturowego Hiszpanii, jej tożsamości, działań na rzecz realizacji interesów narodowych w kraju i za granicą, itp. Kierowane przez Santiago Abascala ugrupowanie stara się dotrzeć ze swym przekazem także do osób młodych, którzy - jak wskazano - są dość licznie reprezentowani w jego elektoracie. Vox wykorzystuje w tym zakresie media społecznościowe. U schyłku 2018 r. był pierwszą partią, która zaznaczyła swoją obecność na tak chętnie użytkowanej przez tę część populacji platformie Instagram. Strona internetowa formacji na jesieni 2018 r. odnotowała ponad 600 tys. wizyt, plasując się w czołówce sił politycznych tak widocznych i aktywnych w Internecie (Viejo, 2018, s. 6). Wykorzystuje również inne nośniki i platformy wirtualne - m.in. Facebook i YouTube. Przestrzeń ta jest przez przedstawicieli partii doceniana jako ważny element strategii zyskiwania poparcia społecznego dzięki nowoczesnym metodom komunikowania się z odbiorcami.

Reasumując, radykalna prawica w Hiszpanii potrzebowała długiego czasu, aby zaistnieć w widoczny sposób w przestrzeni politycznej. Dopiero w ostatnich latach wi- 
dać wzrost sympatii wyborczych wobec ugrupowania o takim charakterze, szczególnie wśród radykalizujących się przedstawicieli dawnego elektoratu Partii Ludowej - m.in. drobnych przedsiębiorców, obawiających się skutków ekonomicznych napływu imigrantów. Vox reprezentuje w Hiszpanii nurt radykalnej prawicy, co odzwierciedla szereg typowych elementów dyskursywnych, znajdujących wyraz w programie ugrupowania i wypowiedziach jego polityków. Wśród nich należy wymienić przede wszystkim: nacjonalizm i natywizm, deklarowaną konieczność obrony tradycyjnie rozumianych wartości, neoliberalizm gospodarczy, silne akcenty antyimigranckie. Owemu spectrum ideowemu towarzyszą także wyznaczniki znamienne dla specyfiki determinantów społecznych i politycznych Hiszpanii: postulaty ochrony dziedzictwa narodowego i jego symboli, resentymenty historyczne, zwalczanie tendencji odśrodkowych oraz promowanie ujednoliconego wizerunku państwa, w dużym stopniu przez pryzmat tradycyjnej kultury kastylijskiej.

Trudno prognozować, jak kształtować się będzie poparcie dla Vox-u, jednak nie wydaje się, aby w najbliższym czasie ugrupowanie to zniknęło z pejzażu politycznego Hiszpanii. Nie można odmówić mu efektywności w procesie umacniania swej pozycji. Jego sytuacja jest obecnie stabilna, co widać w sondażach, z których wynika, że jest ono trzecią siłą na scenie politycznej tego państwa. Widać wyraźnie, że program formacji wpisuje się w nastroje sporej grupy wyborców, w tym także tych „antysystemowych”, poszukujących nowej, atrakcyjnej reprezentacji politycznej. W zrozumieniu uwarunkowań społecznych i psychologicznych poparcia dla Vox-u i podobnych partii nie należy również zapominać o znaczeniu czynnika swoistej społecznej anomii, w sensie odczuwania przez część ich elektoratu poczucia zagubienia, niepewności i obaw o los swój oraz bliskich (Climent Sanjuan, Montaner Goetzenberger, 2020, s. 920-921). Nie sposób nie dostrzec, że niepewność ta jest również pogłębiana gospodarczymi skutkami pandemii koronawirusa, które dla Hiszpanii okazały się bardzo dotkliwe. Badanie przeprowadzone w listopadzie $2020 \mathrm{r}$. wykazało, że partia ta uzyskałaby 13,2 proc. głosów (dla porównania: PSOE - 30,4 proc., a PP - 18,6 proc. poparcia) (de Grado, 2021). Jest zatem jasne, że niemała część wyborców, w tym „dysydentów” Partii Ludowej, lokuje swe sympatie polityczne w tym ugrupowaniu oraz utożsamia się z jego przekazem $\mathrm{i}$ hasłami. Jest też prawdopodobne, że odniesione w lutym 2021 r. zwycięstwo separatystów w wyborach do parlamentu Katalonii zintensyfikuje retorykę Vox-u, wymierzoną przeciwko tendencjom secesjonistycznym.

Jak trwałe okażą się obecne rządy lewicy w Hiszpanii w dużym stopniu zależeć będzie od efektywności władz uporania się ze skutkami gospodarczymi pandemii koronawirusa oraz innymi wyzwaniami społecznymi i ekonomicznymi. W przypadku spadku poparcia dla PSOE i wzrostu sympatii dla prawicy, w rezultacie kolejnych wyborów parlamentarnych, możliwym wariantem wydaje się być koalicja PP i Vox-u, która mogłaby umożliwić temu ugrupowaniu realizację części swych postulatów. Scenariusz ten obecnie nie wydaje się prawdopodobny, ale nie należy go wykluczać. Tak czy inaczej, nie ulega wątpliwości, że także i w Hiszpanii wyraźnie zaznaczyły się postawy tradycjonalistyczne i konserwatywne, które znalazły silną reprezentację polityczną.

Jakkolwiek w najbliższej przyszłości w Hiszpanii, nie wydaje się prawdopodobny gwałtowny wzrost tych nastrojów, niemniej retoryka skierowana przeciwko separatyzmom regionalnym czy muzułmanom może powracać, szczególnie w przypadku nara- 
stania kryzysu imigracyjnego i wyzwań społeczno-ekonomicznych oraz uwidaczniania się procesu polaryzacji społeczeństwa hiszpańskiego. Stąd też tak potrzebne jest rozwijanie projektów inkluzji oraz integracji w stosunku do odmiennych kulturowo społeczności, co przyczynić się może w konsekwencji do niwelowania barier i wzajemnych uprzedzeń oraz osłabić oddziaływanie populistycznego dyskursu. Wspieranie dialogu międzykulturowego sprzyja, jak wiadomo, osłabianiu konfliktów i coraz lepszemu współistnieniu poszczególnych grup w ramach tak zróżnicowanego charakteru społeczeństwa Hiszpanii.

\section{Bibliografia}

Amengay A., Stockemer D. (2018), The Radical Right in Western Europe: A Meta-Analysis of Structural Factors, „Political Studies Review”, 1-11.

Bocanegra J. (2020), Vox defiende la educación segregada frente al "asalto" de la ley Celaá: "Beneficia a las niñas”, „El Confidencial”, 11 de noviembre de 2020, https://www.elconfidencial.com/ espana/2020-11-11/vox-defiende-educacion-segregada-ley-celaa_2827579/, 9.01.2021.

Casalas X. (2017), La evolución de la ultraderecha: claves históricas y territoriales, Real Insitututo Elcano, „ARI”, 59.

Cercas J. (2009), Anatomía de un instante, Debols!llo, Barcelona.

Chislett W. (2018). Spain no longer bucks the trend on far-right parties, Real Instituto Elcano, „ARI”, 54.

Chodubski A. (2004), Wstęp do badań politologicznych, Wydawnictwo Uniwersytetu Gdańskiego, Gdańsk.

Climent Sanjuan V., Montaner Goetzenberger M. (2020), Los partidos populistas de extrema derecha en Espana: Un análisis sociológico comparado, „Izquierdas”, 49, junio 2020.

¿Cometen los extranjeros más delitos que los españoles?, „Parainmigrantes.info”, 17 de septiembre de 2019, https://www.parainmigrantes.info/cometen-los-extranjeros-mas-delitos-que-los-espanoles/, 6.12.2019.

Cs crece en la encuesta de CIS tras facilitar los Presupestos y Vox también avanza tras su moción, https://www.elperiodico.com/es/politica/20201118/encuesta-cis-barometro-noviembre-2020psoe-pp-cs-vox-up-8209914, 10.01.2021.

de Grado A. (2021), El CIS de Trenazos premia a Vox tras la moción de censura, castiga al PP y dispara a Arrimadas, https://okdiario.com/espana/cis-tezanos-deja-pp-casi-12-puntos-distancia-delpsoe-premia-arrimadas-6450834, 2.01.2021.

de la Torre C. (2007), ¿Es el populismo la forma constitutiva de la democracia en Latinoamérica?, w: Vox populi. Populismo y democracia en Latinoamérica, red. J. Aibar Gaete, Flacso, México.

Ferreira C. (2019), Vox como un representate de la derecha radical en España: un estudio sobre su ideología, „Revista Española de Ciencia Política”, noviembre 2019, 51.

Freidenberg F. (2007), La tentación populista. Una vía al poder en América Latina, Editorial Sintesis, Madrid.

García España E. (2018), La delincuencia y la inmigración: dos fenómenos sin relación, „El Diario. es", 5 de febrero de 2018.

Gómez-Reino Cachafeiro M. (2019), Caridad o necesidad? La política de ayuda y la explosión populista, Real Instituto Elcano, „ARI”, 81/2019.

González M. (2019), Vox se convierte en tercera fuerza del nuevo Congreso, „El País”, 19 de noviembre de 2019. 
Gran acto de VOX en Vistalegre \#EspañaViva, http://bit.ly/32LMHbJ.Vox, 11.12.2020.

https://www.voxespana.es/, 4.01.2021.

Huysmans J. (2000), The European Union and the Securitization of Migration, „Journal of Common Market Studies", vol. 38, issue 5.

Kasprowicz D. (2017), Populistyczna radykalna prawica jako obszar badawczy, Instytut Dziennikarstwa, Mediów i Komunikacji Społecznej Uniwersytetu Jagiellońskiego, Kraków.

Kosmynka S. (2020a), Desafios para la seguridad de España por parte del yihadismo en el contexto del impacto del Estado Islámico, w: Situación política de España a finales del siglo XX y a proncipios del siglo XXI, red. S. Dudara, J. Iwanek, E. Tarnawski, Oficyna Wydawnicza Uniwersytetu Zielonogórskiego, Zielona Góra.

Kosmynka S. (2020c), The Pakistani Community in Spain: Social and Cultural Challenges, „Acta Universitatis Lodziensis. Folia Sociologica", 74.

Kosmynka S. (2020b), Udział Hiszpanii w misjach bezpieczeństwa w Sahelu Zachodnim, „Athenaeum. Polskie Studia Politologiczne", 65(1).

Lipczak A. (2020), Lajla znaczy noc, Karakter, Warszawa.

Marcet J. (2012), La derecha en España: una aproximación histórica, „Working Papers”, 306, Barcelona.

Mudde C. (2007), Populist Radical Right Parties in Europe, Cambridge University Press, Cambridge.

Ortiz Barquero P. (2019), The Electoral Breakthrough of the Radical Right in Spain: Correlates of Electoral Support for VOX in Andalusia (2018), „Genealogy” 3, 72.

Programa electoral para las elecciones autonómicas de 2019, http://bit.ly/2NfhQxJ, 15.12.2020.

Rubio-Pueyo V. (2019), Vox ¿una nueva extrema derecha en España?, Rosa Luxemburg Stiftung, Nueva York.

Sasot M. (2019), Un consejal de Vox retira un busto de Abderramán III en un pueblo de Zaragoza, „La Vanguardia", 19 de junio de 2019.

Sául Vargas Paredes M. (2009), Introducción, w: Liderazgo, políticas públicas y cambio organizacional. Lecciones desde Iberoamérica, red. M. Sául Vargas Paredes, Miguel Ángel Porrúa, México.

Turrnbull-Dugarte S., Rama J., Santana A. (2020), The Baskerville's dog suddenly started barking: voting for VOX in the 2019 Spanish general elections, „Political Research Exchange”, vol. 2, issue 1.

Viejo M. (2018), La estrategia de Vox en redes sociales: ya es el primer partido en Instagram, la plataforma con más jóvenes, „El País”, 16 de diciembre de 2018.

Vox Huelva, 31 de octubre de 2019, https://www.voxespana.es/noticias/ortega-smith-cada-vez-somosmas-espanoles-dispuestos-cambiar-rumbo-espana-20191031, 9.01.2021.

Ziętek A. W. (2017), Sekurytyzacja migracji w bezpieczeństwie kulturowym Europy, „Teka Komisji Politologii i Stosunków Międzynarodowych", 12/3.

\section{„Make Spain great”. The Vox party as the emergence of the radical right in the Iberian Peninsula}

\section{Summary}

The paper shows the phenomenon of the radical right in Spain in the context of the Vox party. It analyses the social and political conditions of the emergence of the populist radical right in the Iberian Peninsula and the ideological background of the Vox party. The article refers to its discursive strategy that is based on nationalism and nativism. It is also focused on the most important dimensions and fac- 
tors of support for the party and on the social profile of its followers. The methodological analysis is based on the integration of historical and system method and refers to Cas Mudde's concept of populist radical right. The main purpose of the paper is to approximate some crucial aspects of the ideology and political project presented by the Vox party. The main conclusion of the article is that the radical right in Spain, after the long-term lack of progress, has managed to occupy an important place in the Spanish politics. The Vox phraseology is accepted by some conservative voters opposed to the tradicional establishment. The paper analyses the components of the Vox strategy which emphesize the impact of the multicultural society on the threat for the Spanish identity and traditional values.

Key words: Vox, Spain, extreme right, nationalism, immigrans, identity 
